\title{
Who Speaks for the Village? Representing and Practicing the "Rural" in India from the Colonial to the Post-Colonial
}

Joël Cabalion and Delphine Thivet

\section{(2) OpenEdition}

\section{Journals}

Electronic version

URL: http://journals.openedition.org/samaj/5384

DOI: $10.4000 /$ samaj.5384

ISSN: 1960-6060

Publisher

Association pour la recherche sur l'Asie du Sud (ARAS)

Electronic reference

Joël Cabalion and Delphine Thivet, « Who Speaks for the Village? Representing and Practicing the

"Rural" in India from the Colonial to the Post-Colonial », South Asia Multidisciplinary Academic Journal

[Online], 21 | 2019, Online since 24 July 2019, connection on 17 September 2019. URL : http:// journals.openedition.org/samaj/5384; DOI : 10.4000/samaj.5384

This text was automatically generated on 17 September 2019

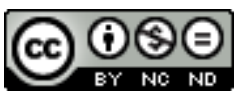

This work is licensed under a Creative Commons Attribution-NonCommercial-NoDerivatives 4.0 International License. 


\title{
Who Speaks for the Village? Representing and Practicing the "Rural" in India from the Colonial to the Post-Colonial
}

\author{
Joël Cabalion and Delphine Thivet
}

Building on a diverse body of research from four disciplines (anthropology, history, sociology and literary studies); this volume aims at re-opening the chapter on the Indian rural social space in relation to the category of the village in colonial and postcolonial India. This issue, "Who Speaks for the Village" would like to raise two sets of questions, both linked to representative

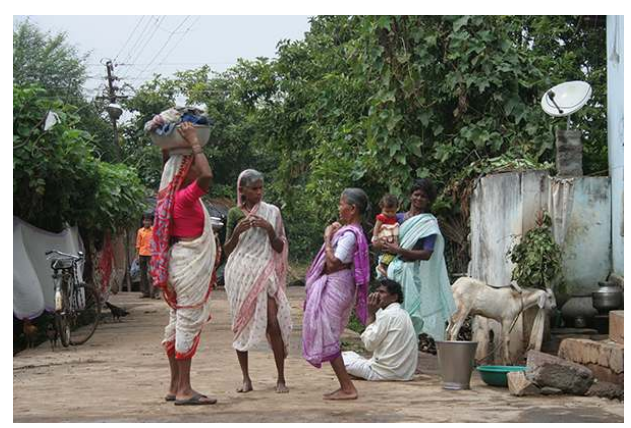
politics as well as more disciplinary concerns with existing perimeters of research on the rural. While there existed an almost mythical field of village studies in the Indian context, mostly fed by anthropological and folklorist research, former orientations seem to have contemporaneously diverged into at least three or four streams of interest, each contributing to a growing body of work on the transformations of rural India: action-research in rural development (alternately techno-managerial or movementist-often concerned with forced displacement), agrarian and/or development studies (often embedded in various revamped Marxist economic perspectives studying regimes of dispossession), rural studies intertwining ethnographic and sociological methods combined with a renewed interest for "local social space" (Laferté 2014) and the "social resilience" (Lamont and Hall 2013) of actors in today's neoliberal era. ${ }^{1}$ In the midst of such a differentiated literature covering vastly changing topographical and social realities, this issue claims to be only a partial attempt at finding out some of the fracturing lines in the rural today. 


\section{Inheriting "Village Studies." Why does the Rural Still Matter in Twenty-first Century India?}

2 In the context of rapid urbanization, current urban-led economic growth and the emergence of the "global-and-smart-cities" agenda in India, there has been little space for rural and agrarian concerns-since the early 1990s-in either regional or national priorities. In the field of politics, the salience of villages has been devalued in a fashion similar to that experienced by non-communal, grassroots committees (sangharsh samiti). For example, leftist social movements which address rural issues have gradually weakened in the face of "mandal-mandir" politics. $^{3}$ And yet, ignoring provincial areas can be perilous at a time when, despite a considerable increase in the absolute size of the urban population, about $67 \%$ of Indians still live outside the cities.

3 As it is well known, the ideal, as much as the morphological reality of villages, has been a core of Indian history and policy. Since colonial times, Indian villages have been conceived as harmonious if not sleepy "small republics" governed by moral economies ${ }^{4}$ and marshalled as relevant microcosms for understanding the greater Indian culture and society (Marriott 1955:171). ${ }^{5}$ It would be beyond the scope of this introduction to engage with a social history of the genesis of village studies as part of a larger postwar framework of development and modernization and its present academic currency or epistemological importance in the field of Indian studies. This has been amply outlined a number of times (Madan 2002; Thakur 2013; Jodhka 2016). Now, at least since the economic reforms in 1991, certain issues have largely overshadowed the village per se to privilege other analytical entries, viz. development, displacement, non-farm employment and economic diversification, intra-rural migration, local democracy, education, etc. Even if they lack the conceptual unification ${ }^{6}$ and academic patronage, and thereby legitimacy, that contributed to their success in the 1950s to the early 1970s, village, or for that matter rural, studies are far from being moribund and represent on the contrary an important field of investigation for social science researchers from India and elsewhere. ${ }^{7}$

4 In spite of the vagueness and ambiguity of contemporary geographical contours ${ }^{8}$ and social boundaries, ${ }^{9}$ of the village, it is indeed still a matter of interest for academics. We herein contend that rural studies, that is, studies on the issue of "the rural" as a site as well as an object/category of study in itself, are dynamic and may in fact capture very well the complex realities of Indian society over time and space. The village is far from being invisible, un-represented or unspoken of in academic research. Despite the obvious domination of urban studies, it is still obvious that rural studies still offer valuable information on the movement of morphological changes around the country by focusing on a few particular themes, whether in sociology, anthropology, economics, history and/ or political sciences.

5 The purpose of this issue is thus to reassert that village and rural studies are a legitimate and crucial area of research through which to understand the important social, economic, political and cultural dynamics and tensions which mark the trajectory of Indian society over time. Rural India calls out for investigations into a context fraught with the disintegration of the village as "a social, economic, and cultural unit" (Jodhka and D'Souza 2009:153). Far from having a socially cohesive character, rural space in India is increasingly becoming divided, by, inter alia, religious fundamentalism and neoliberal 
onslaughts on the commons. However, the fragmentation of the village is not necessarily negative per se nor antithetical to the process of democratization at the local level; for instance, the distancing of local Dalits from the traditional agrarian economy has helped to a certain extent to weaken the traditional hierarchical structures and to allow the raising of new claims over resources that were commonly in the control of the upper/ dominant caste groups in the village (Jodhka 2007:28). Replying to the question "Who speaks for the village?" thus requires us to explore the socioeconomic, cultural and political hierarchies in local contexts and the complex recomposition over time and space of the power relationships between, but also within, castes, classes and genders. This is the reason why this issue aims to analyze the heterogeneity of Indian rural social space, its stratification and deeply entrenched economic and social divisions, varying over time and regions, from the colonial to the post-colonial era. It investigates in particular the actors, external or internal to rural society, who claim to represent the "village," and how internal social differentiation is being addressed. Furthermore, it investigates the transformation of agrarian struggles through the lens of dispossession-related resistances. Finally, this issue examines fictional, visual and literary, representations of the village and its residents (Lagrave 1980). In a manner similar to other national contexts, one may say that Indian cultural production, such as literature and film, has tended to disseminate over time the "dominant point-of-view of the urban imaginary, anchor[ing] the village in a national text" and erasing all traces of autonomous subaltern narration and rural self-representation (Selim 2004:228). As the Indian population and diaspora become increasingly urbanized, competing visions are appearing: the countryside and its inhabitants tend to be idealized and mythologized, whereas as the same time, Bollywood movies, for instance, reflect a "dream world" ever increasingly distanced from the everyday reality of lower middle class and rural audiences (Rao 2007). ${ }^{10}$ Furthermore, Tejaswini Ganti observes that "the rural" in Indian film-makers' discourse is merely "a trope to signify social worlds and markets that are regarded by film makers as backward, traditional, outmoded, and unprofitable" (Ganti 2012:318).

Overall, the ambition of this special issue is therefore to address rurality through representation. Following a constructivist approach, we propose to define rurality, in line with the words of the human geographer, Michael Woods, as "an imagined entity that is brought into being by particular discourses of rurality that are produced, reproduced and contested by academics, the media, policy-makers, rural lobby groups and ordinary individuals" (Woods 2011:9). From this angle, we seek to explore "how different communities define and 'know' the rural" (Heley and Jones 2012:209), but also to take into consideration this polyvocality: who does speak for/about/of/against/with the village? These different aspects of the representations and practices of the "village" and its social components, contributing to the social production of rural space, are herein studied from a range of different disciplinary perspectives, such as history, political science, sociology, anthropology, and literary studies/theory.

\section{The "Agrarian Crisis" Narrative}

7 The early 2000s sparked a new wave of interest in rural life although considered generally a "problem" and the antithesis to the "larger design and desire of a globalizing India" (Vasavi 2012:144). The Indian "village community" indeed seems to have been overtaken by the emergency narrative of the "agrarian crisis," the latter resulting from the 
marginalization of the agrarian agenda in regional and national politics since the early 1990s. Recent efforts by the Indian government under the Bharatiya Janata Party (BJP) to give high priority to the agricultural sector ${ }^{11}$ will be challenged to reverse the bleak picture of Indian agriculture that has dominated for the last twenty to thirty years as India's ongoing transition from a rural to urban society has been accompanied by steady decline of agriculture since the "liberalization" of the Indian economy in 1991 (Bhalla and Singh 2009). Admittedly this liberalization marked the "reinvention of India as a market economy" rather than a critical break (Cordbridge and Harriss 2000), but it nevertheless accelerated the transformation of the agricultural sector by diluting import restrictions, opening up India's agrarian economy to international private corporations and world-market influence and gradually removing state support to agriculture. Since then, a new significant narrative of "agrarian crisis" and "rural distress" has infused public life and the media (Jodhka 2012), a narrative much less articulate when it comes to present and explain the various forms of farmer mobilization still in existence across the country.

8 A good illustration of the above is the issue of "farmers' suicides" in India, which offers a counter-narrative to the new dominant "shining" India discourse. While it can quite justifiably appear as a co-constructed media and political issue (Establet 2012), local and regional statistics (depending upon certain methodological choices [Mishra 2014]) can yet relativize the classic Durkheimian perspective, according to which suicides are statistically more prevalent in urban areas as opposed the rural (Durkheim 1897). It is indeed a well-established, but maybe not-so-well unpacked, sociological mantra: poverty protects against suicide, particularly in close-knit communities where the social structure is implicitly posited as stable or at least more cohesive. When social transformations occur on a very large scale, as modernization theory posits, the morbidity trend of suicide reflects a convergence of rates of increase in urban areas where social agents are considered more vulnerable to the effects of modernization. Establet shows that we can confirm this effect of social evolution in the Indian case as well. ${ }^{12}$ However, the statistical apparatus used is critically debated. While suicide mortality ratios (SMR) are usually higher for urban areas, it would nonetheless be possible to propose an alternative methodology (Mishra 2014), questioning the rationale of the (former) planning commission which combined cultivators and agricultural laborers to homogenize the apprehension of rural areas. By embracing this former dichotomy to calculate the SMR between the urban and the rural, one obfuscates the possibility of disaggregating statistics by socio-professional category in the rural, a step which would confirm Halbwachs' historical study (1930) on the causes of suicide rather than the work of Durkheim. ${ }^{13}$ Peasant suicides are the suicides of economically and socially downgraded and/or disqualified people. Halbwachs proposed the theory that suicides occur in poor segments of rich regions. This could be applied to India as well, with slight modifications. As it has often been noted, farmer suicides have mostly taken place in particular districts of five states (Maharashtra, Madhya Pradesh, Andhra Pradesh-actually Telangana today, Chhattisgarh and Karnataka). Not all of these states are rich, and not all suicides are committed by the people defined as poor. We can reasonably ask if farmers' suicides may not concern in priority, all things being equal, small and middle-caste peasants facing the constant impossibility to cross the threshold of economic reproduction, while being subjected more and more to a feeling of institutional abandonment. When caste barriers are stronger than solidarities, individual economic logics more pervasive, and state 
intervention a figment of peasant aspirations amongst those who are supposed to fuel agricultural production, then a certain fall in senselessness can become apparent.

The issue of "farmers' suicides," highlighted by the media, nevertheless hides other less visible aspects of the current "crisis" of the Indian countryside. The latter is actually a combination of three crises affecting rural social spaces: economic, social, and environmental, and resulting in multiple risks affecting first and foremost the most marginal within it. Far from being a crisis of peasant subsistence farming, this agrarian crisis in India is one of capitalist agriculture, dependent on world market prices, commercial crops, capital flow and chemical input. It directly affects small and medium farmers who have entered into "cash" crops cultivation, and the technological treadmill which goes with it in areas where this form of agriculture has spread and intensified. Undergoing a process of "secularization" (Vasavi 1994), agriculture is increasingly being defined as an economic enterprise. The question of "who speaks for the village" can here be replaced by the following questions: "Who is a legitimate farmer"? Who is the "good farmer"? Are the poor Adivasi cultivators and marginal peasants at all legitimate in continuing to exist vis-à-vis the current modernization of Indian agriculture? Facing disenchantment as well as multiple opportunities for exit, adult offspring are increasingly engaged in non-agricultural employment. While the agrarian crisis appears to be not only a crisis of social reproduction within the peasantry, but more durably a crisis of vocation -farming activities being increasingly looked down upon by farmers' families themselves (Landy 2011:234)-the social resilience of the Indian farming habitus can also appear remarkable, particularly after wide-scale dispossession and displacement (Cabalion 2013). Who, then, in contemporary India does still wish to undertake farming?

Addressing seriously the agrarian crisis would require recognizing the long-term processes and "everyday" social structures of gender, caste and religion engendering socioeconomic deprivation, inequality in access to resources and ecological degradation. However, as Richa Kumar reminds us, short-term and quick political responses predominate:

The response to indebtedness is a waiver of the current crop of loans, but what happens next year when farmers are forced to take new loans? The reaction to suicides is compensation, but does that help surviving family members to figure out a means of livelihood? Pest resistance is solved in the short term by producing more potent pesticides and more resistant varieties, but that fails to address the root cause of resistance-the monoculture paradigm itself. (Kumar 2016:104)

India is indeed facing the heavy environmental and health costs of the green revolution's techno-economic package (Harriss-White and Janakarajan 2004), which has brought monocultures, hybrid seed varieties and large quantities of chemical fertilizers and pesticides to Indian agriculture. These costs still seem to remain largely unrecognized, though everyone is affected: laborers spraying pesticides and paying for it with their health, urban consumers paying for it with cheap, poisoned food, land paying for it with soil toxicity, farmers paying for it with their lives (Kumar 2016:166). This ecological crisis is undermining the long-term social reproduction of Indian farmers; that is, their very ability to farm in the future. While Prime Ministers call for a "second" (Singh 2011) or "ever" (The Times of India, 2017) green revolution and its correlative (bio)technological package at the policy level, the necessity for an alternative trajectory, viz. an agro ecological transition, begins to arise at the grassroots level. Some farmers' movements are introducing "agronomical pluralism" (Münster 2016:229) by training themselves in agroecology, experimenting with natural/organic farming methods and seeking ways to 
escape the chemical market treadmill. Alternative agricultures, notably the natural farming movement "Zero Budget Natural Farming" in Punjab, Kerala, Karnataka, Tamil Nadu and Andhra Pradesh (Brown 2013, 2018; Thivet 2014; Münster 2016; Khadse et al 2018; Dorin 2018), have emerged in response to the ecological crisis. While they try to offer an alternative to exiting agriculture and to the problem of social reproduction of farmers, their claim for an authentic and "pure India" through the revival of a cultural heritage of Indian agricultural practices (Vasavi 2012; Münster 2014) raises new sets of questions on old issues: the reproduction of power relationships and potential marginalization towards other groups and religious and ethnic minorities living in the countryside.

11 Understanding the complexity of the dynamics at play in the triple "agrarian crisis" (economic, social, environmental) consequently requires us to take into account the diversity of experience of rural inhabitants, in connection with their specific geographically and historically interrelated ecosystems, but also with the sociopolitical, cultural and economic factor shaping their existence. ${ }^{14}$

\section{The Changing Face of Rural Capitalism}

12 As evoked, the category of the rural stands disaggregated into multiple sub-fields of specialization and intervention delineating the very nature and regularity of certain phenomena traversing rural India-poverty, agrarian issues, displacement-and the fabric of public policies and knowledge configuration, particularly in the Indian field of social work, specifically designed to assess their evolution. It is therefore not surprising that studies known as "agrarian," or falling in the larger category of "development" studies, have often been the most vital and instrumental in keeping an eye on rural existence, particularly from Marxist and Ambedkarite perspectives. In brief, after the 1970-1980s, everything happened as though studying rural India was a desirable task if it was to understand its backwardness or to herald the agency of its dominated people. In anthropology too, the scenario has long been to choose between understanding practices that had supposedly not changed, or the public and political contraptions intended to change them, in other words development programs or any public policy which would usher in social change.

Development has brought a new set of vulnerabilities to the countryside. Across the last few decades, struggles over land and its uses in particular received much attention from researchers. Acquisition of land today is mainly directed at nonagricultural development: urbanization, real estate development, industrialization, mining, roads, and other infrastructural projects, etc., created a new demand for rural land (Chakravorty 2013). Unlike the previous expropriations of large amounts of land for public infrastructure (such as large dams) and industries and thermal plants, land acquisition in the neoliberal era, culminating with SEZs (special economic zones), proceeds "under an expansive definition of 'public purpose' that becomes growingly indistinguishable from private capital accumulation. Elite housing colonies, IT parks, malls and amusement parks have joined the hydroelectric dam and steel mill as causes for expropriating the peasantry" (Levien 2012:964). The pushing up of land prices opened up new opportunities for profit and accumulation not only for the high-profile actors such as SEZ developers, real estate companies and the State but also for a wide and yet heterogeneous new class of village and local land brokers permeating the land economy (Levien 2012; Sud 2014). The 
replacement of the antiquated colonial Land Acquisition Act of 1894 with the Right to Fair Compensation and Transparency in Land Acquisition, Rehabilitation and Resettlement (LARR) Act in $2013,{ }^{15}$ has certainly altered the terms and conditions by which land is to be transacted, protecting the rights of those who might be dispossessed and displaced (D'Costa and Chakrabarty 2017). In spite of its determination to make land acquisition less cumbersome, the government elected in 2014, could not, however, gather enough support to alter the 2013 LARR Act. As we are reminded by Christophe Jaffrelot (2018), amending the LARR at the central level partly failed due to the importance of the rural sector as a major voting segment, and despite the assumption that pro-business policies would necessarily prevail over rural interests. The counter-intuitive resilience of this act under the present government may be apprehended globally as a well-known historical pattern of social democracies: when a major "social advantage" is conquered -however disputed and unsurprisingly limited LARR still appears to be for many actors of the social movement industry-even the incumbent winner of the following elections finds it hard to dismantle it. We can draw an analogy between the LARR and the other major central acts that have not been requisitioned by the National Democratic Alliance (NDA) government: the right to information, the Forest rights act or the National food security act. It would, however, be hasty to consider that the LARR has decisively altered the process of dispossession or has been left intact. The strategy has been to dilute it at regional levels by bringing in regional amendments, a step taken by no less than eight states in the country as of the beginning of 2019.

In the past few decades, the village has most notably disappeared behind what we could call "social group studies," whether Dalit or Adivasi studies. Most Dalits and Adivasi inhabit rural areas, even the ex-Mahar of Maharashtra who have converted to Buddhism under the guidance of Ambedkar and who slowly continue to migrate as though following their leader's historic injunction to leave villages ("What is a village but a sink of localism, a den of ignorance and narrow mindedness," [Ambedkar 1979]). Taken in the dust of the Indian agrarian transition, they alternately become minor civil servants, construction laborers in cities, or mine workers. In other words, social group studies have been the study of groups defined or displaced by/from their rural condition of existence, or who may still carry within them a strong rural form of identification. The rural can be defined today as the underside of development, that is, a crucial site of dispossession and displacement, two words that may define appropriately the Indian rural experience of subalternity. Dispossession, however, needs to be understood conceptually beyond the mere experience of land eviction and embrace social relations of domination beyond the single dimension of the land-grabbing State. The privatization of higher education, for instance, appears to be a major social stake of struggles, both conditioned by and leading to an increased state of dispossession of the subaltern rural masses. Selling one's piece of land for an improbable trajectory of success in the educational field is, for instance, more and more common and appears to be an accelerating factor in "depeasantization," often subservient to a social position in the formal sector though frequently at the lowest rungs.

\section{Rural Politics and Emerging Voices of Resistance}

15 Analysis of Indian contemporary politics often fails to take into consideration rural politics, yet, the rural vote bank plays an important role in elections. It is well known that 
the Indian National Congress (INC) Party of the UPA consolidated its rural vote following the implementation of the National Rural Employment Guarantee Act (NREGA) (2006). Viewed from afar, Modi's reign may have appeared consolidated and well installed for at least a second term, crunching on urban voters almost everywhere with major infrastructure projects and wooing the Hindu masses with sage-like neatly controlled media appearances. ${ }^{16}$ It is almost as though the scenario of 2004 (the "India Shining" campaign and its result) and particularly its lessons regarding the rural-urban divide and myth of the Indian middle class had been obliterated in the BJP's memory. 2018 had already disclosed some signs of resistance as the year of kisan marches. The gathering of more than 35,000 farmers in Mumbai in March 2018, then of 100,000 farmers in New Delhi in November 2018 (Kisan Mukti March) to demand that parliament hold a special 21 day session to address the "agrarian crisis" appears to have affected the elections to the legislative assemblies of Rajasthan, Madhya Pradesh and Chhattisgarh, leading to the BJP defeat in these states. Even though traversing India's countryside gives a glimpse of a certain kind of diffusion of bajrang dal shakas, ${ }^{17}$ numerous dents in Indian secularism and civic liberties when it comes to cow protection and unification of Hindu sentiment, it appears the Hindu ethos still struggles to be a sufficient denominator for Bharat's jawaan and kisaan. ${ }^{18}$ As ordinary as it may sound, the periodic re-emergence of peasant struggles and (un)employment questions in the face of Hindu mandal-mandir tactics (and despite major media black-outs on their massive protests) show a remarkable resilience which minimizes their devastating effects. Naya zamaanaa ("new times") and acche din ("good days") are still longed for by most farmers if we consider the magnitude of requests for debt-liberation (karz maaphi/mukti) across the country. Hence, beyond the various provisional relief measures carried out to appease the rural electorate, the results of the 2019 election implicitly posited that religious nationalism will continue to strive, as we see it does elsewhere in the present international context, albeit for a range of very heterogeneous reasons. However, the final results of the elections heighten certain preoccupations and require us to sharpen further our analyses regarding the rural and its representational politics in the years to come. We need in particular to go beyond the apparent unity of the Indian countryside and not restrict rural politics to agricultural interests, so as to better understand how the different "contests over the legitimate representation of 'the rural' [might] be articulated" (Woods 2003:323).

Save for electoral politics and the representation of rural interests by formally constituted unions or pressure groups, rural politics indeed also include various social movements contesting the meaning and the use of rural space. Another way to make sense of rural politics is to cast aside our "passive imagination of the rural" which "sees the rural as largely defeated, washed over and worn out, its sell-by date exceeded, with little independence as a source of change in its own right" (Bell, Lloyd, and Vatovec 2010:209). Far from mainstream spaces, less visible representatives of the "rural," such as socialist and communist struggle committees (sangharsh samiti) for forest, water and land rights (jungle, jal aur zameen adhikar) continue to form the backbone of the rural social movement across the country, however sleepy and small they may sometimes be in a period much infused with cultural nationalism. The circulation of activist capital is particularly high in these three spheres, yet does not quite overlap with the actors present in struggles against direct State dispossession and displacement (Cabalion 2014). Such type of convergence between various issue-based struggles is what social leaders wish to structure more durably in the Indian social movement. After displacement, many 
activists themselves concerned by resettlement disengage and disconnect from social action in the movement when they begin their new life, precipitating social movements against displacement in a situation of abeyance due to their sudden lack of activist manpower and/or direct support. Peasant and/or farmer movements as well as social movements against dispossession and displacement, however, share much in common when we consider that they concern actors who have little access to wage labor but face regular threats to their basic economic and social reproduction. The deformalization as well as the commodification of their existence in the face of land evictions, water privatization, and more broadly, degradation of their environment, are important dimensions of the experience of subalternity in Indian villages.

\section{Overview of this Special Issue}

17 To tackle these different facets of the rural in India, this volume brings together multiple disciplinary perspectives and a variety of empirical studies to critically examine the place and relevance of studying the village and rurality. The articles are drawn from a panel convened at the European Conference of South Asian Studies (ECSAS) in Paris in July 2018. What we hereby attempt is not to speak for rural transformations in the subcontinent altogether, but on the contrary to assert the need to study these transformations from multiple perspectives, voices and situations: caste issues, agrarian relations, rural-urban interactions, rural development and rural politics.

18 The first article by Girija Joshi addresses the hegemonic category of the village constructed by the colonial imagination by deconstructing historically the myth of the "eternal village." While India was imagined as a "land of villages" by colonialism, Joshi deals with the particular case of the "Delhi frontier" (rural Haryana), that is, nomadic pastoral populations in the early nineteenth century. She demonstrates that in this mobile agrarian frontier, kinship categories had historically crystallized around the control of land. By implication, kinship was a vehicle of State formation, whose boundaries were determined at least in part by the pragmatic consideration of resource consolidation. Joshi's appreciation of the political dimension of kinship thus brings complexity to our understanding of rural politics, highlighting that the "village community" was far from being a historically stable polity.

In the second article, Ritanjan Das examines a two-decade old process of land acquisition and development in Rajarhat, a former rural settlement in the Indian state of West Bengal, to characterize the transformation of villages amidst rapid urbanization in neoliberal India. Originally made up of almost 50 villages and now a satellite township of the state capital Kolkata, Rajarhat offers "an intriguing window to the subtle, yet multifaceted transformation of socio-economic relations within the remnants of erstwhile rural spaces." Ritanjan Das engages with the new expressions of caste consciousness around the processes of displacement and dispossession due to the Kolkata new town project. While forceful land grabbing and limited compensations reducing farming opportunities for the villagers did not lead to caste-based mobilisation, new forms of economic engagements ("syndicate-raj") contributed to the reproduction of distinct segregations between lower and upper-caste habitations, but also between Muslims and non-Muslims, the spatiality of caste reemerging in Rajarhat "urban" villages. 
20 In the third article, Vikramaditya Thakur explores subaltern agency and the changing nature of leadership in rural western India among the Bhil Scheduled Tribe or Adivasi group in the wake of the anti-dam movement initiated by urban middle-class activists of the Narmada Bachao Andolan (NBA; also Save Narmada Campaign). Drawing on fieldwork data along with oral history, archival research, government records, vernacular records and dailies, Thakur analyses the politics of displacement and resettlement due to the Sardar Sarovar dam on River Narmada as a lived experience of two ordinary Bhil men from the submergence villages in Maharashtra state across three decades from 19852016. He shows how the NBA-led movement acts as a form of political education for the two Bhils who assume leadership, displacing both traditional Bhil leaders and external activists to guide their community deftly to the resettlement colonies by making claims on the Indian state, and help recreate life and livelihood for themselves and their fellow Bhils in the new setting.

21 In his contribution, Jonathan Galton deals with the "village in the city," drawing on a year's ethnographic fieldwork in a Mumbai neighborhood (the Delisle Road BDD Chawls). He reflects on how villages are represented and recreated in a contemporary urban context and how migrants themselves "speak for the village." In particular, he examines how a "simulacrum of the village" arises from circulation migrations, through the phenomenon of Gramastha Mandals, village-run committees that buy and rent chawl (tenement) rooms to single male migrants from their own villages. Originally established in the heyday of the city's cotton mill industry more than fifty years ago, many Gramastha Mandals' rooms now house a third generation of migrants studying or working, mainly in the margins of the shining world of Mumbai city. They offer a window into village life and rural Maharashtra through the young men living in these rooms and perpetuate a sense of village belonging and nostalgia. Constant flows of people, money and ideas between village and chawl contribute to recreate the village in Mumbai through festivals and food practices. However, while residents claim the rooms promote an urbane egalitarianism, they are frequently exclusive spaces, created in the context of historic divisions between communities back in the village. Jonathan Galton shows that their strict eligibility criteria can have the effect of preserving and possibly reinforcing village social divisions, specifically between caste Hindus and Dalit Buddhist communities.

The last article by Angela Eyre explores the history of Indian novels in English representing the village, through the comparison of the setting, publication and reception of two novels. She analyses the representations of one means of radical social change: the peasants' participation in organized rebellion. Mulk Raj Anand's The Sword and the Sickle (1942) narrates a historical uprising in Awadh in 1921-1922. Neel Mukherjee's book, The Lives of Others (2014), alternates between describing the story of Naxalite peasant insurgency between 1967 and 1970 and one about a bourgeois family in Calcutta. An Epilogue dated 2012 connects the historical movement to present Maoist insurgencies. In both novels an outsider to the village introduces revolutionary ideas and, in both, local conditions are connected to national and global ones. Whereas The Sword and The Sickle ends with limited hope for political change within a future Independent nation state, The Lives of Others ends with despair and impending violence and the reasons for this difference are explored. While both novels have voiced peasants' grievances in different ways, Eyre shows how some reviewers almost completely focused on the expression and legitimacy of revolutionary violence, obscuring almost completely the 
peasant struggles. Anand's story was subsumed by concerns about India's role in the Second World War, while some responses to Mukherjee's novel condemned its representation of violence. The novels therefore raise questions not only about who speaks for the village, but also about who is listening and which voices one hears. The violent suppression of peasants' resistance and the "slow violence" that affect, for instance, rural families starving to death are most often left unheard.

Ambedkar, B.R. 1979. "Castes in India: Their Mechanism, Genesis and Development." Pp. 131-53 in Dr. Babasaheb Ambedkar: Writings and Speeches. Vol. I. Education Department, Government of Maharashtra.

Anon. 2017. “'Make Way Not for $2^{\text {nd }}$ Green Revolution, but for Evergreen Revolution,' says PM Narendra Modi." The Times of India, 26 May. Retrieved July 11, 2019, (http:// timesofindia.indiatimes.com/articleshow/58856754.cms? utm_source=contentofinterest\&utm_medium=text\&utm_campaign=cppst).

Bell, Michael M., Sarah E. Lloyd, and Christine Vatovec. 2010. "Activating the Countryside: Rural Power, the Power of the Rural and the Making of Rural Politics." Sociologia Ruralis 50(3):205-24.

Bhalla, Gurmail Singha, and Gurmail Singh. 2009. "Economic Liberalisation and Indian Agriculture: A Statewise Analysis." Economic and Political Weekly 44(52):34-44.

Bo Nielsen, Kenneth. 2018. Land Dispossession and Everyday Politics in Rural Eastern India. London; New York: Anthem Press.

Breman, Jan. 2007. The Poverty Regime in Village India: Half a Century of Work and Life at the Bottom of the Rural Economy in South Gujarat. New Delhi; Oxford: Oxford University Press.

Breman, Jan, Peter Kloos, and Ashwani Saith. 1997. The Village in Asia Revisited. Delhi/Oxford: Oxford University Press.

Brown, Trent. 2013. "Agrarian Crisis in Punjab and 'Natural Farming' as a Response." South Asia: Journal of South Asian Studies 36(2):229-42.

Brown, Trent. 2018. Farmers, Subalterns, and Activists: Social Politics of Sustainable Agriculture in India. Cambridge, England: Cambridge University Press.

Burawoy, Michael. 2009. "The Global Turn: Lessons from Southern Labor Scholars and Their Labor Movements." Work and Occupations 36(2):87-95.

Cabalion, Joël. 2014. “La Question Sociale de la Dépossession.” Mouvements 77:25-33.

Cabalion, Joël. 2013. “Des Existences Paysannes au Fil de l'Eau, Le Grand Barrage Gosikhurd et Les Déplacements de Population." Ph.D. dissertation, Department of Sociology, EHESS.

Chakravorty, Sanjoy. 2013. The Price of Land: Acquisition, Conflict, Consequence. New Delhi: Oxford University Press.

Corbridge, Stuart and John Harriss. 2000. Reinventing India: Liberalization, Hindu Nationalism and Popular Democracy. Cambridge, England: Policy Press.

D'Costa, Anthony and Achin Chakraborty, eds. 2017. The Land Question in India: State, Dispossession, and Capitalist Transition. New Delhi: Oxford University Press.

Deshpande, R.S. and Saroj Arora, eds. 2010. Agrarian Crisis and Farmer Suicides. New Delhi: Sage Publications.

Dorin, Bruno. 2018. Mission ZBNF Andhra: Illustrated Mission Report. New Delhi: Centre de Sciences Humaines. 
Dube, S.C. 1967. Indian Village. New York; Evanston: Harper \& Row.

Dumont, Louis and David F. Pocock. 1957. "Village Studies." Contributions to Indian Sociology 1:2341.

Dumont, Louis. 1980. Homo Hierarchicus: The Caste System and Its Implications. Translated by M. Sainsbury et al. Chicago; London: The University of Chicago Press.

Durkheim, Emile. 1897. Le Suicide. Etude de Sociologie. Paris: Alcan.

Establet, Roger. 2002. “Le suicide en Inde au Début du XXIe Siècle.” Sociologie 3(2):117-43.

Fuller, C.J. 1993. "Misconceiving the Grain Heap: A Critique of the Concept of the Indian Jajmani System. Pp. 33-63 in Money and the Morality of Exchange, edited by J. Parry and M. Bloch. Cambridge, England: Cambridge University Press.

Gallo, Ester. 2015. "Village Ethnography and Kinship Studies: Perspectives from India and Beyond." Critique of Anthropology 35(3):248-62.

Ganti, Tejaswini. 2012. Producing Bollywood: Inside the Contemporary Hindi Film Industry. Durham: Duke University Press.

Halbwachs, Maurice. 2002. Les Causes du Suicide. Paris: Presses Universitaires de France.

Hall, Peter A. and Michèle Lamont. 2013. Social Resilience in The Neoliberal Era. Cambridge, England: Cambridge University Press.

Harriss-White, Barbara and S. Janakarajan, eds. 2004. Rural India Facing the $21^{\text {st }}$ Century: Essays on Long Term Village Change and Recent Development Policy. London; New York: Anthem Press.

Heley, Jess and Laura Jones. 2012. "Relational Rurals: Some Thoughts on Relating Things and Theory in Rural Studies." Journal of Rural Studies 28(3):208-17.

Jha, Himanshu Praveen and Gerry Rodgers, eds. 2016. The Changing Village in India: Insights from Longitudinal Research. New Delhi: Oxford University Press.

Jaffrelot, Christophe. 2018. “Le Capitalisme de Connivence en Inde sous Narendra Modi." Les Etudes du CERI, Study No. 237. Retrieved July 18, 2018 (http://www.scuebcesoi.fr/ceri/fr/content/ le-capitalism-de-connivence-en-inde-sous-narendra-modi).

Jodhka, Surinder S. 2016. "Revisiting the Rural in $21^{\text {st }}$ Century India." Economic and Political Weekly 51(26-27):5-7.

Jodhka, Surinder S. 2012. “Agrarian Changes in the Times of (Neo-Liberal) 'Crises': Revisiting Attached Labour in Haryana." Economic and Political Weekly 47(26-27):5-13.

Jodhka, Surinder S. 2007. Who Will Speak for the Village? Agrarian Change and Marginalizing Ruralities in Contemporary India. Presented at Department of Sociology: University of Pune.

Jodhka, Surinder S. 2006. "Caste and Democracy: Assertion and Identity Among the Dalits of Rural Punjab.” Sociological Bulletin 55(1):4-23.

Jodhka, Surinder S. and Paul D’Souza. 2009. "Rural and Agrarian Studies.” Pp. 118-84 in Sociology and Social Anthropology in India, edited by Y. Atal. New Delhi: Pearson Education.

Khadse, Ashlesha, Peter Rosset, Helda Morales, and Bruce G. Ferguson. 2018. "Taking Agroecology to Scale: The Zero Budget Natural Farming Peasant Movement in Karnataka, India." The Journal of Peasant Studies 45(1):192-219.

Kumar, Richa. 2016. Rethinking Revolutions: Soybean, Choupals, and the Changing Countryside in Central India. New Delhi: Oxford University Press. 
Laferté, Gilles. 2014. “Des Études Rurales à l'Analyse des Espaces Sociaux Localisés.” Sociologie 5 (4):423-39.

Lagrave, Rose-Marie. 1980. Le Village Romanesque. Le Paradou: Éditions Actes Sud.

Landy, Frédéric. 2011. “Une Majorité Délaissée? La Situation Ambiguë des Campagnes de l'Inde.” Pp. 229-48 in Dynamiques des Espaces Ruraux dans le Monde, edited by M. Guibert and Y. Jean. Paris: Armand Colin.

Lerche, Jens, Alpa Shah, and Barbara Harriss-White. 2013. "Introduction: Agrarian Questions and Left Politics in India." Journal of Agrarian Change 13(3):337-50.

Levien, Michael. 2012. "The Land Question: Special Economic Zones and the Political Economy of Dispossession in India." The Journal of Peasant Studies 39(3-4):933-69.

Madan, Vandana. 2012. The Village in India. Delhi: Oxford University Press.

Marriott, McKim, ed. 1955. Village India: Studies in the Little Community. Chicago: University Chicago Press.

Mishra, Srijit. 2014. “Farmers' Suicides in India, 1995-2012: Measurement and Interpretation.” LSE ARC Working Papers, Working Paper 62.

Mishra, Srijit and Narasimha D. Reddy. 2010. "Economic Reforms, Small Farmer Economy and Agrarian Crisis." Pp. 43-69 in Agrarian Crisis and Farmer Suicides, edited by R. S. Deshpande and S. Arora. New Delhi: Sage Publications.

Münster, Daniel. 2014. “A Letter to Subhash Palekar, Natural Farmer.” RCC Perspectives 6:23-26.

Münster, Daniel. 2016. “Agro-Ecological Double Movements? Zero Budget Natural Farming and Alternative Agricultures After the Neoliberal Crisis in Kerala." Pp. 222-44 in Critical Perspectives on Agrarian Transition: India in the Global Debate, edited by B. B. Mohanty. New Delhi: Routledge.

Münster, Daniel and Ursula Münster. 2012. "Consuming the Forest in an Environment of Crisis: Nature Tourism, Forest Conservation and Neoliberal Agriculture in South India." Development and Change 43(1):205-27.

Münster, Daniel. 2012. "Farmers' Suicides and the State in India: Conceptual and Ethnographic Notes from Wayanad, Kerala." Contributions to Indian Sociology 46(1-2):181-208.

Omvedt, Gail. 2005. “Farmer's Movements and the Debate on Poverty and Economic Reforms in India." Pp. 179-202 in Social Movements in India: Poverty, Power, and Politics, edited by R. Ray and M. F. Katzenstein. Lanham: Rowman \& Littlefield.

Rao, Niranjan G. and D. Narasimha Reddy, eds. 2008. Rural Transformation: Perspectives from Village Studies in Andhra Pradesh. Delhi: Danish Books.

Rao, Shakuntala. 2007. "The Globalization of Bollywood: An Ethnography of Non-Elite Audiences in India." The Communication Review 10(1):57-76.

Reddy, D. Narasimha and Srijit Mishra, eds. 2009. Agrarian Crisis in India. New Delhi: Oxford University Press.

Selim, Samah. 2004. The Novel and the Rural Imaginary in Egypt, 1880-1985. New York: Routledge/ Curzon.

Simpson, Edward. 2016. "Village Restudies: Trials and Tribulations." Economic and Political Weekly 51(26-27):33-42.

Singh, Manmohan. 2011. "PM's Address at $83^{\text {rd }}$ Foundation Day of ICAR." July 16. Retrieved July 11, 2019 (http://www.pib.nic.in/newsite/erelcontent.aspx?relid=73296). 
Srinivas, Mysore Narasimhachar, ed. 1955. India's Villages. Bombay; Calcutta; New Delhi; Madras; Lucknow; London; New York: Asia Publishing House.

Sud, Nikita. 2014. "The Men in the Middle: A Missing Dimension in Global Land Deals." The Journal of Peasant Studies 41(4):593-612.

Thakur, Manish K. 2013. “Of 'Village Studies' and the 'Village': A Disputed Legacy.” Sociological Bulletin 62(1):138-51.

Thivet, Delphine. 2014. “Chapitre 4. La Vía Campesina et l'Appropriation de l'Agroécologie." Pp. 75-92, in Dynamiques des Agricultures Biologiques. Effets de Contexte et Appropriations, edited by A. Cardona, F. Chrétien, B. Leroux, F. Ripoll, and D. Thivet. Versailles: Editions Quæ.

Vasavi, A.R. 2012. Shadow Space: Suicides and the Predicament of Rural India. Gurgaon: Three Essays Collective.

Woods, Michael. 2003. "Deconstructing Rural Protest: The Emergence of a New Social Movement." Journal of Rural Studies 19:309-25.

Woods, Michael. 2011. Rural. Oxon: Routledge.

\section{NOTES}

1. These are quite evidently not hermetic segments of research and shall be understood as broad descriptive categories.

2. With regard to the Mandal Commission, and mandir for (Hindu) temple, as referred by G. Omvedt 2005.

3. The acquisition of the $\mathrm{OBC}$ (Other Backward Classes) status by Marathas in Maharashtra is a recent illustration of such a "caste-social-movement" coloured by saffron ideology.

4. Such as the religious-economic jajmani system, a traditional Indian institution which institutionalized non-contractual, inter-familial and inter-generational reciprocity between upper landowning castes and other service castes in rural India (Dumont 1980; Dube 1967; for an alternative interpretation, see for instance Fuller 1993).

5. The relevance of the village as a representative unit for understanding the Indian society was contested in Dumont and Pocock (1957).

6. It may not be for the worse, as previous prevalent frameworks (notably functionalist ones) often occurred under the umbrella of harmonist, irenic if not orientalist representations of the village as small and stable coherent entities.

7. The restudies of villages (Simpson 2016)-through longitudinal studies following the same village or set of villages over time-seems rather vivid (Breman, Kloos, and Saith 1997; Rao, Reddy 2010) such as in the case of micro-economic studies on Palanpur (Himanshu, Jha, Rodgers 2016).

8. "Rural" is often defined negatively, as "non-urban." The 1971 Census of India defined an "urban" area as an area with (i) a minimum population of 5,000; (ii) at least 75 percent of the male working population in non-agricultural jobs; (iii) a population density of at least $400 \mathrm{sq}$. Km. 9. One has indeed to take into consideration the importance of networks, flows, connections and mobilities in constituting the rural space (Woods 2011:40). That is why Esther Gallo advocates, for instance, the merging of village ethnography within a larger "multi-sited strategy," given that 
the "villages lie at the heart of increasing connections between mobile people, who engage with kinship through remittances, material exchanges and memory work" (Gallo 2015:250).

10. On the gentrification of the Indian film industry, see Ganti (2012).

11. The contribution of agriculture to GDP has declined to about 16 percent today from 50 percent in the 1950s. Trying to reverse this trend, the Finance Minister of India, Arun Jaitley, declared the Union Budget 2018-2019 to be a "farmer' Budget" (January 2018) and Prime Minister Narendra Modi announced his government was working towards "ensuring that the incomes of [the Indian] hardworking farmers doubles by 2022" (June 2018).

12. "[The Indian case represents a] good occasion to inspect, data in hand, the effects of evolution without having to succumb to the lure of evolutionism" (Establet 2012:118; our translation).

13. Such a methodological choice cannot be equated with the GoI's position which recently changed (after 2014) and now records only the suicides of legitimate landholders-cultivators, deliberately ignoring the ones of landless agricultural labourers. There is an obvious difference between fixing the figures and disaggregating them for the benefit of sociological understanding. 14. For instance, Jens Lerche, Alpa Shah and Barbara Harriss White invite us to pluralize the "agrarian question," so as to take into account not only "the different meanings of the agrarian question," but also the "plurality of agrarian questions in India," that is, "a set of regionally specific agrarian questions" due to the "important regional differences in agricultural productivity, in the significance of agriculture in the economy and, not the least, a plurality of underlying class relations and processes of class formation" (2013:339).

15. The Act was introduced by the United Progressive Alliance (UPA) alongside other "rightsbased" legislations such as Forest Rights, the National Rural Employment Guarantee Act (NREGA), Education, Food and Security.

16. Modi has not given a single "traditional" press conference during his term, preferring to appear and present his (non-contradicted) views on a monthly radiophonic and TV-adapted allocation called "Mann ki baat."

17. The Bajrang Dal is a religious militant organization that forms the youth wing of the Vishva Hindu Parishad (VHP).

18. Double meaning of youth and soldier, with reference here to an old political slogan of Lal Bahadur Shastri in 1965, former Prime Minister, "Jai jawaan, jai kisaan" (Hail the soldier, hail the farmer).

\section{ABSTRACTS}

The idea of the village has been central throughout Indian history. Since colonial times, Indian villages have been pictured as "small republics" and as a relevant microcosm for understanding Indian society at large. Combining the issue of representation with that of rurality, this special issue investigates the actors, be they external or internal to rural society, who claim to represent the "village," and how its internal social differentiation is being addressed: who does speak for/ about/of/against/with the village? The different aspects of the representations and practices of the "rural" and its social components, contributing to the social production of rural space, are herein studied from a range of different disciplinary perspectives, such as history, political science, sociology, anthropology, and literary studies/theory. At last, the purpose of this issue is to reassert village and rural studies as a legitimate and crucial area of research through which to 
understand the important social, economic, political and cultural dynamics and tensions which mark the trajectory of Indian society over time.

INDEX

Keywords: India, rural, village, agrarian crisis, farmers, representation, dispossession

\section{AUTHORS}

JOËL CABALION

Université de Tours, Tours - France

\section{DELPHINE THIVET}

Université de Bordeaux, Bordeaux - France 